\title{
Urinary hippuric acid excretion as related to changes in cell wall digestibility due to variation in degradable protein supply
}

\author{
F. J. Giraldez' , E. Zorita ${ }^{2}$ and R. Pelaez ${ }^{2}$ \\ ${ }^{1}$ CSIC Apartado 788, 24080 León, Spain \\ ${ }^{2}$ Departamento de Producción Animal, Universidad de León, 24007 León, Spain
}

\section{Introduction}

It has been established that dietary phenolic cinnamic acids are the main source of the hippuric acid excreted in ruminant urine. However, changes in hippuric acid output due to variation in the extent of cell wall digestion have so far received little attention.

\section{Material and methods}

To study the effect of rumen degradable protein (RDP) : metabolizable energy (ME) ratio on cell wall digestibility and its relationship to the urinary output of hippuric and benzoic acids three levels of ME (0.19 s.d. 0.003 (1), 0.35 s.d. 0.005 (2) and 0.49 s.d. 0.039 (3) MJ ME per kg live weight (LW) ${ }^{0.75}$ per day) and five levels of RDP (1.69 s.d. 0.069 (A), 2.02 s.d. 0.026 (B), 2.80 s.d. 0.057 (C), 3.26 s.d. 0.056 (D) and 4.14 s.d. 0.048 (E) g RDP per $\mathrm{kg} \mathrm{LW}^{0.75}$ per day) were supplied to 45 mature Merino ewes in a $3 \times 5$ factorial design. RDP represents potential degradable protein determined by the in sacco procedure.

Forage : concentrate ratios in the experimental diets (dry matter basis) were $64.5: 35.5$ (1), $43.6: 56.4$ (2) and $29.5: 70.5$ (3). The forage was a mixture of barley straw and a low-quality meadow hay in proportions $59: 41$ (1), $50: 50$ (2) and $39: 61$ (3). Concentrates, offered as pellets, were formulated from sodium caseinate, gluten meal, tapioca meal and sunflower oil in different proportions to achieve the experimental range of RDP : ME ratios. Neutraldetergent fibre (NDF) intakes $\left(\mathrm{g} / \mathrm{kg} \mathrm{LW} \mathrm{LW}^{0.75}\right.$ per day) were 12.6 s.e. $0.054,13.93$ s.e. 0.15 and 14.56 s.e. 0.17 to levels 1, 2 and 3 of ME intake, respectively. For acid-detergent fibre (ADF) the corresponding figures were 8.01 s.e. $0.04,8.62$ s.e. 0.07 and 8.92 s.e. 0.06 . All diets included a mineral and vitamin supplement, equivalent to $0.5 \mathrm{~g} / \mathrm{kg}$ LW per day, and were offered in two equal meals daily.

The experimental period lasted 23 days. During the first 10 days animals received diet $2-C$ and then the experimental diets for 13 days. Total collection of faeces and urine (by self-retaining urethral catheters) being carried out during the last 5 days.

\section{Results and discussion}

NDF and ADF digestibility and free benzoic and hippuric acid outputs are shown in Tables 1 and 2, respectively.

As was expected NDF and ADF digestibilities were influenced by RDP intake. This effect changed with level of ME intake. At level 1, RDP supply was negatively correlated with NDF $(r=-0.67, P<0.01)$ and $\operatorname{ADF}(r=-0.72, P<0.01)$ digestibilities. However, at the highest level, these correlations were positive $(r=+0.75, P<0.001$ and $r=+0.72, P<0.001$, respectively).

When NDF digestibility $(Y$ ) data were analysed according to the following variance-covariance model: $\ln Y i j=\mu+M E i j+b \times \ln X i j+c \times X i j+e i j$, derived from the gamma function, $X$ being the RDP : ME ratio, it was observed that the effects of both covariables were statistically significant $(P<0.05)$. Below a RDP : ME value of 7.5 , a tendency $(b=+0.3)$ to increase NDF digestibility with RDP supply was observed but this tendency was negative $(c=-0.04)$ when RDP : ME ratios on the diet were above that value.

Although the variability between animals within groups in the amount of hippuric acid excreted in the 
Table 1 Digestibility data

\begin{tabular}{|c|c|c|c|c|c|c|c|c|}
\hline \multirow{2}{*}{$\begin{array}{c}\text { Rumen degradable } \\
\text { protein } \\
\text { (g/kg LW } W^{0.75} \text { per day) }\end{array}$} & \multicolumn{4}{|c|}{$\begin{array}{l}\text { NDF digestibility for ME inputs } \\
\text { (MJ/kg LW }{ }^{0 / 75} \text { per day) of: }\end{array}$} & \multicolumn{4}{|c|}{$\begin{array}{l}\text { ADF digestibility for ME inputs } \\
\text { (MJ/kg LW }{ }^{0.75} \text { per day) of: }\end{array}$} \\
\hline & 0.19 & 0.35 & 0.49 & Mean & 0.19 & 0.35 & 0.49 & Mean \\
\hline $\begin{array}{l}1 \cdot 69 \mathrm{~A} \\
2 \cdot 02 \mathrm{~B} \\
2 \cdot 80 \mathrm{C} \\
3 \cdot 26 \mathrm{D} \\
4 \cdot 14 \mathrm{E}\end{array}$ & $\begin{array}{l}44 \cdot 55 \\
48 \cdot 05 \\
40 \cdot 82 \\
39 \cdot 62 \\
39.56\end{array}$ & $\begin{array}{l}48.93 \\
46 \cdot 80 \\
49.69 \\
43 \cdot 61 \\
40.83\end{array}$ & $\begin{array}{l}34.65 \\
39.00 \\
39.66 \\
41.00 \\
47.61\end{array}$ & $\begin{array}{l}42 \cdot 71^{a} \\
44 \cdot 62^{a} \\
43 \cdot 39^{a} \\
41 \cdot 41^{a} \\
42 \cdot 67^{a}\end{array}$ & $\begin{array}{l}46 \cdot 19 \\
47 \cdot 25 \\
42 \cdot 16 \\
41 \cdot 62 \\
40 \cdot 44\end{array}$ & $\begin{array}{l}47 \cdot 98 \\
46 \cdot 66 \\
49.92 \\
43 \cdot 21 \\
38 \cdot 07\end{array}$ & $\begin{array}{l}27 \cdot 84 \\
36 \cdot 64 \\
37 \cdot 50 \\
37 \cdot 61 \\
44.95\end{array}$ & $\begin{array}{l}40 \cdot 67^{\mathrm{a}} \\
43 \cdot 52^{\mathrm{a}} \\
43 \cdot 19^{\mathrm{a}} \\
40 \cdot 81^{\mathrm{a}} \\
42 \cdot 15^{\mathrm{a}}\end{array}$ \\
\hline $\begin{array}{r}\text { Mean } \\
\text { Residual s.d. }\end{array}$ & $42.52^{\mathrm{a}}$ & $\begin{array}{c}45.97^{b} \\
3.32\end{array}$ & $40 \cdot 38^{a}$ & & $43.54^{\text {ab }}$ & $\begin{array}{c}45 \cdot 17^{b} \\
3.50\end{array}$ & $36 \cdot 91^{a}$ & \\
\hline
\end{tabular}

a,b Means in the same row or column with different superscript letter were significantly different $(P<0.05)$.

Table 2 Acid cxcretion data

\begin{tabular}{|c|c|c|c|c|c|c|c|c|}
\hline \multirow{2}{*}{$\begin{array}{c}\text { Rumen degradable } \\
\text { protein } \\
\text { (g/kg LW } W^{0.75} \text { per day) }\end{array}$} & \multicolumn{4}{|c|}{$\begin{array}{c}\text { Benzoic acid excretion } \\
\text { (mg/kg LW }{ }^{0.75} \text { per day) for ME } \\
\text { inputs (MJ/kg } W^{0.75} \text { per day) of: }\end{array}$} & \multicolumn{4}{|c|}{$\begin{array}{l}\text { Hippuric acid excretion } \\
\text { (mg/kg LW } W^{(1.75} \text { per day) for } \mathrm{ME} \\
\text { inputs }\left(\mathrm{M} J / \mathrm{kg} L W^{0-75} \text { per day) of: }\right.\end{array}$} \\
\hline & 0.19 & 0.35 & 0.49 & Mean & 0.19 & 0.35 & 0.49 & Mean \\
\hline $\begin{array}{l}1 \cdot 69 \mathrm{~A} \\
2 \cdot 02 \mathrm{~B} \\
2 \cdot 80 \mathrm{C} \\
3 \cdot 26 \mathrm{D} \\
4 \cdot 14 \mathrm{E}\end{array}$ & $\begin{array}{r}5.08 \\
11.42 \\
19.75 \\
19.43 \\
15.50\end{array}$ & $\begin{array}{r}2.23 \\
9.49 \\
24.92 \\
22 \cdot 18 \\
29.86\end{array}$ & $\begin{array}{r}5.95 \\
11.24 \\
14.99 \\
32.40 \\
48.51\end{array}$ & $\begin{array}{c}4 \cdot 42^{a} \\
10 \cdot 72^{a b} \\
19 \cdot 89^{b c} \\
24 \cdot 67^{c d} \\
31 \cdot 29^{d}\end{array}$ & $\begin{array}{r}102.32 \\
155 \cdot 10 \\
120 \cdot 86 \\
128 \cdot 24 \\
81 \cdot 03\end{array}$ & $\begin{array}{r}102.04 \\
105.84 \\
136.90 \\
128.97 \\
91.84\end{array}$ & $\begin{array}{r}30.22 \\
56.55 \\
58.97 \\
73.06 \\
115.23\end{array}$ & $\begin{array}{r}78.19^{a} \\
105.83^{a} \\
105.58 \\
110.09^{a} \\
96.04^{a}\end{array}$ \\
\hline $\begin{array}{l}\text { Mean } \\
\text { Residual s.d. }\end{array}$ & $14 \cdot 24^{\prime \prime}$ & $\begin{array}{l}17.74^{\mathrm{a}} \\
11 \cdot 82\end{array}$ & $22 \cdot 62^{a}$ & & $117 \cdot 51^{b}$ & $\begin{array}{c}113 \cdot 12^{b} \\
27 \cdot 22\end{array}$ & $66.81^{a}$ & \\
\hline
\end{tabular}

a,b,c,d Means in the same row or column with different superscript letters were significantly different $(P<0.05)$.

urine was very high $(\mathrm{CV}=\mathbf{0 . 2 7 5 2 )}$, hippuric output was correlated with NDF digestibility $(r=+0.78$, $P<0.001)$ and ADF digestibility $(r=+0.78, P<0.001)$, provided RDP supply was equal to or lower than the estimated nitrogen requirements of the rumen microorganisms (Agricultural Research Council, 1980).

Urinary free benzoic acid was not affected by changes in NDF or ADF digestibilities but was correlated with RDP intake $(r=+0.64, P<0.001)$. This coefficient was higher $(r=+0.74)$ when the results of treatments with excess RDP were not taken into account.

On the other hand, benzoic acid conjugation rate, which ranged from $90.04 \% \pm 3.67$ (level $A$ ) to $67.63 \%$ \pm 4.13 (level E), also appears to be related to RDP supply $(r=-0.59, P<0.001)$.

\section{Conclusions}

When there is a deficit of RDP, cell wall digestibility is affected probably due to a limited ability of animals to recycle nitrogen. Surplus of RDP also appears to reduce cell wall digestibility and it could be related with the cellulolytic bacterial growth. The experimental results indicate that renal excretion of hippuric acid may reflect, to some extent, changes in cell wall digestibility due to deficiencies in RDP of the diet.

\section{Acknowledgement PROYECTO CICYT (GAN 88-0071).}

\section{Reference}

Agricultural Research Council. 1980. The nutrient requirements of farm livestock. No. 2. Ruminants. Commonwealth Agricultural Bureaux, Slough. 